\title{
Is it possible to reduce the surgical mortality and morbidity of peptic ulcer perforations?
}

Adnan Hut ${ }^{1}$, Cihad Tatar², Doğan Yıldırım¹, Turgut Dönmez ${ }^{3}$, Akın Ünal', Ahmet Kocakuşak¹, Muzaffer Akıncı

ABSTRACT

Cite this paper as: Hut A, Tatar C, Yıldırım D, Dönmez T, Ünal A, Kocakuşak $A$, et al. Is it possible to reduce the surgical mortality and morbidity of peptic ulcer perforations? Turk J Surg 2017; 33: 267-273.

'Department of General Surgery, Haseki Training and Research Hospital, Istanbul, Turkey 2Department of General Surgery, İstanbul Training and Research Hospital, İstanbul, Turkey ${ }^{3}$ Department of General Surgery, Lütfiye Nuri Burat State Hospital, İstanbul, Turkey

Address for Correspondence Cihad Tatar

e-mail: tatarcihad@gmail.com

Received: 25.07.2016

Accepted: 17.10 .2016

(C) Copyright 2017 by Turkish Surgical Association

Available online at www.turkjsurg.com
Objective: Peptic ulcer perforation is a life-threatening situation requiring urgent surgical treatment. A novel vision in peptic ulcer perforation is necessary to fill the gaps created by antiulcer medication, aging of the patients, and presentation of resistant cases in our era. In this study, we aimed to share our findings regarding the effects of various risk factors and operative techniques on the mortality and morbidity of patients with peptic ulcer perforation.

Material and Methods: Data from 112 patients presenting at our Training and Research Hospital Emergency Surgery Department between January 2010 and December 2015 who were diagnosed with PUP through physical examination and laboratory and radiological tests and operated at the hospital have been retrospectively analyzed. Patients were divided into three groups based on morbidity (Group 1), mortality (Group 2), and no complication (Group 3).

Results: Of the 112 patients included in the study, morbidity was observed in 21 (18.8\%), mortality in 11 (9.8\%), and no complication was observed in $80(71.4 \%)$, who were discharged with cure. The differences between group for the average values of the perforation diameter and American Society of Anesthesiologists, Acute Physiology and Chronic Health Evaluation II, and Mannheim Peritonitis Index scores were statistically significant ( $p<0.001$ for each). The average values for the group with mortality were significantly higher than those of the other groups.

Conclusion: In this study where we investigated risk factors for increased morbidity and mortality in PUPs, there was statistically significant difference between the average values for age, body mass index, perforation diameter, and Acute Physiology and Chronic Health Evaluation II and Mannheim Peritonitis Index scores among the three groups, whereas the amount of subdiaphragmatic free air did not differ.

Keywords: Mortality, perforation, peptic ulcer perforation, risk factors

\section{INTRODUCTION}

With regard to creating a novel vision for former diseases, our memorizationsshould be updated. Some diseases and their outcomes, which have been previously very well known, are nowadays almost always presented as unexpected cases because of new technologies and evolvements in medicine due to resistant events. Thus, antiulcer medication and presentation of elderly patients have changed in peptic ulcer perforation (PUP) and, transforming the patient profiles with PUP in our era. Therefore, a novel vision to avoid gaps is necessary to evaluate the patients with PUPsas surgeons are coming across newer patient profiles in last decades. Peptic ulcers are focal defects in the stomach and the duodenum extending below the mucosa or deeper $(1,2)$. They can be acute or chronic; the etiology of the condition is the disruption of balance between gastric acid effect and mucosal defense mechanisms $(2,3)$. Although medical treatments such as $\mathrm{H} 2$ receptor antagonists, proton pump inhibitors, and Helicobacter pylori eradication through antibacterial drugs, have decreased the number of surgeries in non-complicated peptic ulcer cases, the number of patients presenting to the emergency clinics with peptic ulcer perforation has not decreased (1-5).

Peptic ulcer perforation is still an important health problem, despite the decreasing incidence of peptic ulcer disease. The aim of this study was to investigate factors affecting the mortality and morbidity of PUPs and specifically determine approaches to decrease mortality.

\section{MATERIAL AND METHODS}

The data from 112 patients operated with the diagnosis of PUP at our Training and Research Hospital between January 2010 and December 2015 were retrospectively analyzed. Patient age, gender, weight, height, American Society of Anesthesiologists (ASA) score, symptoms, time interval between symptom onset and surgery, accompanying diseases, length of hospital stay, operative technique, laboratory findings, site and diameter of perforation, Acute Physiology and Chronic Health Evaluation (APACHE) II and Mannheim Peritonitis Index (MPI) scores, preoperative shock state, morbidity, and mortality were recorded. MPI (Table 1) and APACHE II scores were calculated for all patients. Patient age, chronic health status, rectal temperature, mean arterial blood pressure, heart rate, respiratory rate, arterial $\mathrm{pH}$, partial oxygen pressure, serum sodium, serum potassium, serum creatinine, hematocrit, white blood cell count, and Glasgow coma score were recorded for determining the APACHE II score. 
All patients were operated with the open technique. After the aspiration of the intraabdominal free fluid, the intraperitoneal cavity was irrigated with at least $1000 \mathrm{~mL}$ of isotonic saline and aspirated. The surgical procedure was determined by the operating surgeon and either one of omental patch with Gra-

Table 1. Mannheim peritonitis index

\begin{tabular}{|l|c|}
\hline Risk factor & Weighting if present \\
\hline Age $>50$ years & 5 \\
\hline Female sex & 5 \\
\hline Organ failure & 7 \\
\hline Malignancy & 4 \\
\hline Preoperative duration of peritonitis $>24 h$ & 4 \\
\hline Origin of sepsis not colonic & 4 \\
\hline Diffuse generalized peritonitis & 6 \\
\hline
\end{tabular}

Exudate

$\begin{array}{lc}\text { Clear } & 0 \\ \text { Cloudy, purulent } & 6 \\ \text { Fecal } & 12\end{array}$

Definitions of organ failure

\begin{tabular}{|l|c|}
\hline Kidney & $\begin{array}{c}\text { Cratine level }>177 \mu \mathrm{mol} / \mathrm{L} \\
\text { Urea level }>167 \mathrm{mmol} / \mathrm{L} \\
\text { Oliguria }<20 \mathrm{~mL} / \mathrm{h}\end{array}$ \\
\hline Lung & $\mathrm{PO}_{2}<50 \mathrm{mmHg}$ \\
$\mathrm{PCO}_{2}>50 \mathrm{mmHg}$ & $\begin{array}{c}\text { Hypodynamic or } \\
\text { hyperdynamic }\end{array}$ \\
\hline Shock & $\begin{array}{c}\text { Paralysis }>24 \mathrm{~h} \text { or } \\
\text { complete mechanical } \\
\text { obstruction }\end{array}$ \\
\hline Intestinal obstruction
\end{tabular}

$\mathrm{PO}^{2}: \mathrm{PCO}^{2}$ ham's procedure, bilateral truncal vagotomy with pyloroplasty or, antrectomy and gastroenterostomy was applied. Patients were divided into three groups based on morbidity (Group 1), mortality (Group 2), and no complication (Group 3).

Written informed consent of the included patients and local ethics committee approval were obtained.

\section{Statistical Analysis}

Statistical Package for Social Sciences software version 15.0 (SPSS Inc.; Chicago, IL, USA) was used for statistical analysis. Descriptive statistics were presented with number and percentage for categorical variables and mean, standard deviation, minimum, maximum, and median values for numerical variables. Comparisons between more than two independent groups were made using the one-way Anova test for normal distribution of numerical values and the Kruskal-Wallis test when normal distribution was not present. Subgroup analyses were carried out with the Tukey test for parametric tests and the Mann-Whitney $U$ test for non-parametric tests and interpreted using the Bonferroni correction. The ratio of categorical variables between groups was tested using the chi square analysis. Risk factors for morbidity and mortality were evaluated using Cox regression analysis. Statistical significance level was accepted as $p<0.05$.

\section{RESULTS}

Of the 112 patients included in the study, morbidity was observed in 21 (18.8\%) and mortality in 11 (9.8\%). Eighty (71.4\%) patients were discharged with cure, free of complications. Ninety-seven (86.6\%) of 112 patients were male and 15 (13.4\%) were female. No significant difference in the gender distribution of the groups was detected $(p=0.252)$. There was statistically significant difference between the mean age of the groups $(p<0.001)$. The mean age of the group with mortality was significantly higher than the that of the morbidity and no complication groups, and the mean age of the morbidity group was significantly higher than that of the no complication group. The demographic data and subgroup analyses are presented in Table 2-4.

Table 2. Demographics

\begin{tabular}{|c|c|c|c|c|c|c|c|c|}
\hline & & \multicolumn{2}{|c|}{ Non-complicated } & \multicolumn{2}{|c|}{ Morbidity } & \multicolumn{2}{|c|}{ Mortality } & $p$ \\
\hline Gender & Male & \multicolumn{2}{|c|}{$71(88.8)$} & \multicolumn{2}{|c|}{$18(85.7)$} & \multicolumn{2}{|c|}{$8(72.7)$} & 0.252 \\
\hline & Female & Mean $\pm S D$ & Median & Mean $\pm S D$ & Median & Mean $\pm S D$ & Median & \\
\hline \multicolumn{2}{|l|}{ Age } & $30.7 \pm 12.8$ & 29 & $53.0 \pm 16.6$ & 60 & $70.2 \pm 15.1$ & 73 & $<0.001$ \\
\hline \multicolumn{2}{|l|}{ Weight } & $67.5 \pm 14.0$ & 66 & $80.8 \pm 11.6$ & 82 & $82.1 \pm 4.6$ & 83 & $<0.001$ \\
\hline \multicolumn{2}{|l|}{ Height } & $175.6 \pm 7.6$ & 175 & $169.0 \pm 6.6$ & 169 & $167.6 \pm 7.6$ & 169 & $<0.001$ \\
\hline \multicolumn{2}{|l|}{ BMI } & $22.0 \pm 5.2$ & 21.2 & $28.5 \pm 4.9$ & 28.1 & $29.4 \pm 2.9$ & 30.1 & $<0.001$ \\
\hline \multicolumn{2}{|c|}{ Time from onset of symptoms } & $1.5 \pm 1.3$ & 1 & $3.0 \pm 2.0$ & 2 & $4.6 \pm 1.6$ & 4 & $<0.001$ \\
\hline \multicolumn{2}{|c|}{ Duriation of hospital stay (days) } & $5.3 \pm 1.1$ & 5 & $11.7 \pm 11.3$ & 7 & $9.2 \pm 6.2$ & 10 & $<0.001$ \\
\hline \multicolumn{2}{|l|}{ ASA } & $1.1 \pm 0.3$ & 1 & $2.1 \pm 0.9$ & 2 & $3.6 \pm 0.9$ & 4 & $<0.001$ \\
\hline \multicolumn{2}{|c|}{ APACHE II score } & $2.0 \pm 2.5$ & 1 & $4.5 \pm 3.2$ & 5 & $10.2 \pm 5.3$ & 9 & $<0.001$ \\
\hline \multicolumn{2}{|c|}{ MPI score } & $2.4 \pm 3.6$ & 0 & $9.2 \pm 6.5$ & 6 & $18.5 \pm 6.4$ & 17 & $<0.001$ \\
\hline
\end{tabular}


The mean body mass index (BMI) of the patients were significantly different among groups $(p<0.001)$. The average BMI in the mortality and morbidity groups was significantly higher than that in the no complication group.

Table 3. Subgroup analyses of demographics

\begin{tabular}{|lccc|} 
& $\begin{array}{c}\text { Non-complicated } \\
\text { vs } \\
\text { Morbidity }\end{array}$ & $\begin{array}{c}\text { Non-complicated } \\
\text { vs } \\
\text { Mortality }\end{array}$ & $\begin{array}{c}\text { Morbidity } \\
\text { vs } \\
\text { Mortality }\end{array}$ \\
\hline Age & $\mathbf{p}$ & $\mathbf{p}$ & $\mathbf{p}$ \\
\hline Weight & $<0.001$ & $<0.001$ & 0.003 \\
\hline Height & 0.001 & $<0.001$ & 0.842 \\
\hline BMI & $<0.001$ & 0.003 & 0.875 \\
\hline $\begin{array}{l}\text { Time from onset of } \\
\text { symptoms }\end{array}$ & $<0.001$ & $<0.001$ & 0.858 \\
\hline $\begin{array}{l}\text { Duriation of hospital } \\
\text { stay (days) }\end{array}$ & $<0.001$ & $<0.001$ & 0.013 \\
\hline $\begin{array}{l}\text { Perforation } \\
\text { diameter (mm) }\end{array}$ & 0.001 & 0.110 & 0.857 \\
\hline ASA & $<0.001$ & $<0.001$ & 0.003 \\
\hline APACHE II score & 0.001 & $<0.001$ & $<0.001$ \\
\hline MPI score & $<0.001$ & $<0.001$ & 0.001 \\
\hline
\end{tabular}

BMI: body mass index; ASA: American Society of Anesthesiologists; APACHE: acute physiology and chronic health evaluation; MPI: Mannheim peritonitis index
There was significant difference between groups with regard to time interval between symptom onset and surgery $(p<0.001)$. The time interval was significantly higher in the mortality group than in the morbidity and no complication groups, and significantly higher in the morbidity group than in the no complication group. Statistically significant difference was observed in duration of hospital stay $(p<0,001)$. The average duration of hospital stay in the group with morbidity was significantly longer than that in the no complication group.

The differences between the average values of the diameter of perforation and ASA, APACHE II and MPI scores among groups were statistically significant ( $p<0.001$ for each). The average values for the group with mortality were significantly higher than those for the morbidity and no complication groups. Likewise, the average values for the morbidity group were significantly higher than those for the no complication group. In 98 (87.5\%) patients, subdiaphragmatic free air was detected in the initial erect abdominal X-ray. There was no statistically significant difference between the rate of presence of free air between the groups. The white blood cell (WBC) count was $17.045 \pm 13.517$ for Group 1, 13.347 \pm 6.434 for Group 2 and $14.608 \pm 3.857$ for Group 3. No statistically significant difference was detected between the groups $(p=0.734)$. The laboratory findings and subgroup analyses of the groups are displayed in Table 5, 6.

The presence of accompanying diseases showed a statistically significant difference between groups for all but ischemic

Table 4. Subgroup analyses of findings

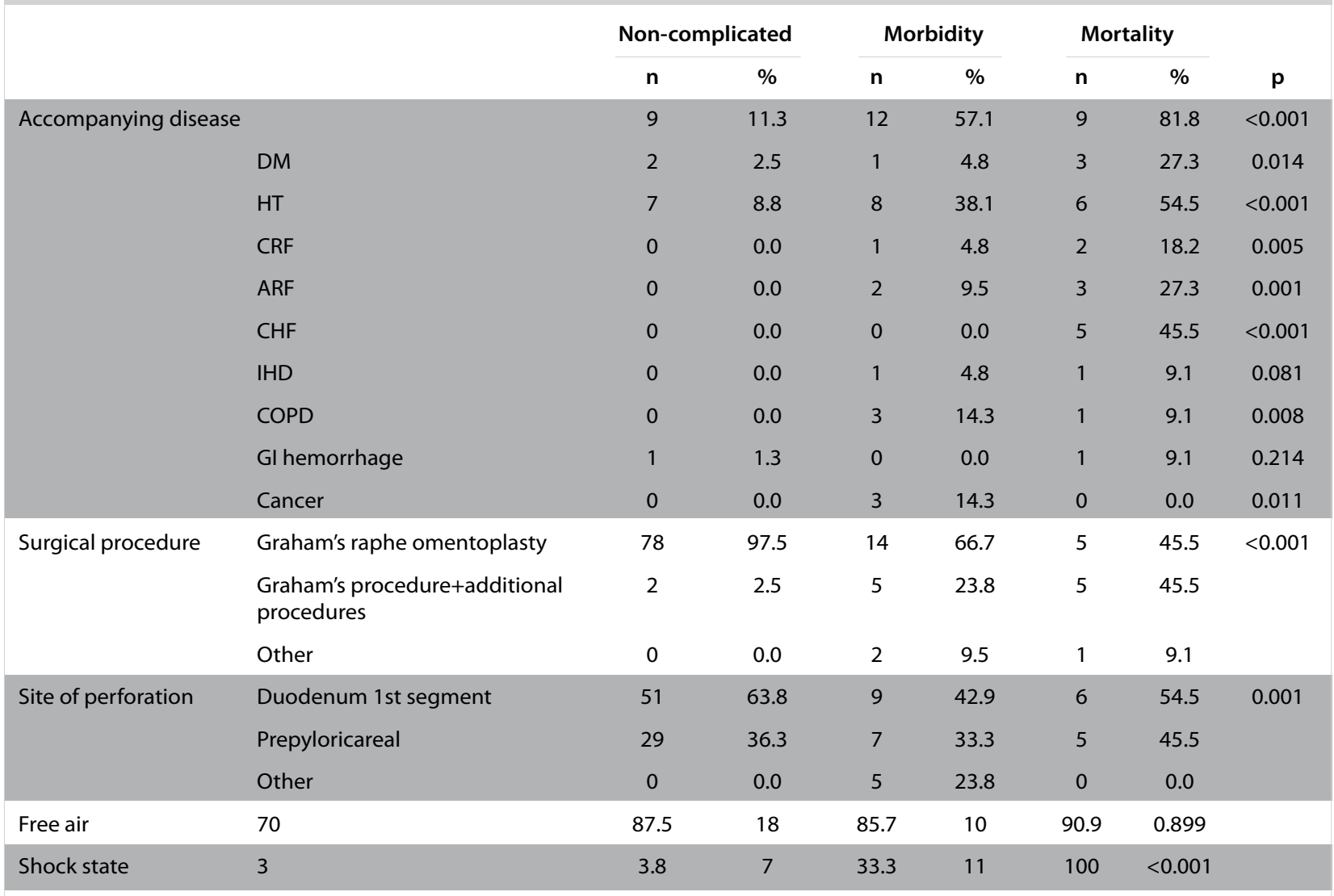

DM: diabetes mellitus; $\mathrm{HT}$ : hypertension; CRF: chronic renal failure; ARF: acute renal failure; CHF: congestive heart failure; IHD: ischemic heart disease; COPD: chronic obstructive pulmonary disease; $\mathrm{Gl}$ : gastrointestinal 
Table 5. Laboratory findings

\begin{tabular}{|c|c|c|c|c|c|c|c|}
\hline & \multicolumn{2}{|c|}{ Non-complicated } & \multicolumn{2}{|c|}{ Morbidity } & \multicolumn{2}{|c|}{ Mortality } & \multirow[b]{2}{*}{$\mathrm{p}$} \\
\hline & Mean \pm SD & Median & Mean \pm SD & Median & Mean \pm SD & Median & \\
\hline Glucose & $130.9 \pm 41.8$ & 121 & $133.6 \pm 52.6$ & 123 & $136.8 \pm 38.4$ & 137 & 0.783 \\
\hline Urea & $33.0 \pm 13.6$ & 32.2 & $59.6 \pm 33.4$ & 52.7 & $108.0 \pm 43.1$ & 90.4 & $<0.001$ \\
\hline Creatinine & $1.0 \pm 1.3$ & 0.78 & $1.4 \pm 1.0$ & 1.14 & $2.4 \pm 1.7$ & 2.1 & $<0.001$ \\
\hline AST & $25.8 \pm 14.6$ & 22 & $31.0 \pm 21.1$ & 26 & $36.8 \pm 21.1$ & 28 & 0.013 \\
\hline ALT & $18.6 \pm 8.9$ & 17 & $30.3 \pm 48.3$ & 18 & $16.1 \pm 6.9$ & 14 & 0.547 \\
\hline GGT & $20.7 \pm 15.6$ & 17 & $41.5 \pm 24.1$ & 34 & $29.5 \pm 18.0$ & 26 & $<0.001$ \\
\hline $\mathrm{LDH}$ & $233.8 \pm 139.3$ & 194 & $242.3 \pm 91.2$ & 234 & $318.1 \pm 106.2$ & 323 & 0.009 \\
\hline ALP & $75.2 \pm 39.3$ & 67 & $101.8 \pm 55.2$ & 83 & $89.6 \pm 23.8$ & 89 & 0.001 \\
\hline Total protein & $7.5 \pm 0.4$ & 7.4 & $7.1 \pm 0.9$ & 7.1 & $5.4 \pm 0.7$ & 5.44 & $<0.001$ \\
\hline Albumin & $4.0 \pm 0.4$ & 3.9 & $3.6 \pm 0.5$ & 3.8 & $2.6 \pm 0.5$ & 2.6 & $<0.001$ \\
\hline Calcium & $9.3 \pm 0.5$ & 9.42 & $9.0 \pm 0.5$ & 9.04 & $8.5 \pm 0.9$ & 8.31 & $<0.001$ \\
\hline Sodium & $136.2 \pm 3.0$ & 136 & $135.0 \pm 3.7$ & 134 & $136.2 \pm 6.2$ & 133 & 0.192 \\
\hline Potassium & $4.1 \pm 0.4$ & 4.075 & $4.2 \pm 0.3$ & 4.22 & $4.9 \pm 0.9$ & 4.8 & 0.007 \\
\hline CRP & $26.0 \pm 50.2$ & 4.4 & $60.2 \pm 97.5$ & 15.58 & $174.6 \pm 190.1$ & 95 & $<0.001$ \\
\hline Amilase & $83.8 \pm 70.6$ & 65.1 & $77.9 \pm 33.6$ & 80.4 & $117.9 \pm 104.9$ & 100.9 & 0.460 \\
\hline WBC & $13.6 \pm 4.2$ & 13.4 & $11.6 \pm 3.9$ & 11.7 & $13.0 \pm 6.4$ & 11.7 & 0.222 \\
\hline HGB & $14.7 \pm 2.0$ & 14.6 & $13.9 \pm 2.2$ & 14.2 & $12.2 \pm 3.3$ & 11.3 & 0.026 \\
\hline $\mathrm{HCT}$ & $44.2 \pm 5.6$ & 44.55 & $43.0 \pm 5.3$ & 42.8 & $37.1 \pm 10.4$ & 34.5 & 0.150 \\
\hline PLT & $257.0 \pm 69.5$ & 242 & $281.6 \pm 70.1$ & 272 & $333.4 \pm 209.7$ & 289 & 0.250 \\
\hline
\end{tabular}

AST: aspartate aminotransferase; ALT: alanine aminotransferase; GGT: gamma glutamyl transferase; LDH: lactate dehydrogenase; ALP: alkaline phosphatase; CRP: C reactive protein; WBC: white blood cells; HGB: hemoblobin; HCT: hematocrit; PLT: platelet

Table 6. Subgroup analyses of laboratory findings

\begin{tabular}{|lccc|} 
& $\begin{array}{c}\text { Non-complicated } \\
\text { vs } \\
\text { morbidity }\end{array}$ & $\begin{array}{c}\text { Non-complicated } \\
\text { vs } \\
\text { mortality }\end{array}$ & $\begin{array}{c}\text { Morbidity } \\
\text { vs } \\
\text { mortality }\end{array}$ \\
\hline Urea & $\mathbf{p}$ & $\mathbf{p}$ & $\mathbf{p}$ \\
\hline Creatinine & $<0.001$ & $<0.001$ & 0.002 \\
\hline AST & 0.039 & $<0.001$ & 0.047 \\
\hline GGT & 0.186 & 0.004 & 0.190 \\
\hline LDH & $<0.001$ & 0.097 & 0.147 \\
\hline ALP & 0.140 & 0.006 & 0.031 \\
\hline Total protein & 0.001 & 0.027 & 0.984 \\
\hline Albumin & 0.285 & $<0.001$ & $<0.001$ \\
\hline Calcium & 0.012 & $<0.001$ & $<0.001$ \\
\hline Potassium & 0.005 & $<0.001$ & 0.057 \\
\hline CRP & 0.199 & 0.004 & 0.025 \\
\hline HGB & 0.002 & $<0.001$ & 0.007 \\
\hline
\end{tabular}

AST: aspartate aminotransferase; GGT: gamma glutamyl transferase; LDH: lactate dehydrogenase; ALP: alkaline phosphatase; CRP: $C$ reactive protein; HGB: hemoblobin

heart disease and gastrointestinal hemorrhage. The presence of accompanying diseases was most frequent in the mortality group, with chronic obstructive pulmonary disease (COPD)
The preferred surgical approach showed a statistically significant difference between the groups. In the morbidity and mortality groups, additional procedures to the Graham's procedure were applied. The distribution of the site of perforation was significantly different among groups $(p=0.001)$. In the morbidity group, hemorrhage from other sites was more common. State of shock was another variable showing statistically significant difference in distribution. All patients in the mortality group were in shock state.

In the model developed for determining factors affecting morbidity with single variables (age, BMI, ASA score, accompanying diseases, perforation diameter, MPI score, urea, GGT, ALP, calcium, and $\mathrm{WBC}$ ) the most significant variables were $\mathrm{BMI}$, GGT, and ALP (Table 7, 8). In the multivariate regression analysis for factors affecting morbidity, age was determined to be a significant parameter using the enter and backward method (Table 9).

In the model developed for determining factors affecting mortality with single variables; age, BMI, ASA score, accompanying diseases, perforation diameter, MPI score, APACHE Il score, urea, creatinine, total plasma protein, albumin, calcium, potassium, CRP, hemoglobin, hematocrit levels and platelet counts were determined to be significant predictors (Table 10). In the multivariate regression analysis for factors affecting mortality, age and APACHE II score were determined to be significant parameters using the enter and backward method (Table 11). 
Table 7. Univariate logistic regression analysis for morbidity

\begin{tabular}{|c|c|c|c|c|}
\hline & $p$ & OR & \multicolumn{2}{|c|}{$95 \%$ C.I. } \\
\hline Age & $<0.001$ & 1.046 & 1.020 & 1.073 \\
\hline Gender (female) & 0.894 & 1.097 & 0.280 & 4.296 \\
\hline BMI & $<0.001$ & 1.219 & 1.095 & 1.358 \\
\hline ASA & 0.002 & 2.022 & 1.288 & 3.174 \\
\hline Accompanying disease & 0.001 & 5.407 & 1.976 & 14.794 \\
\hline Perforation diameter & 0.088 & 1.059 & 0.992 & 1.130 \\
\hline APACHE II score & 0.122 & 1.091 & 0.977 & 1.218 \\
\hline MPI score & 0.006 & 1.095 & 1.026 & 1.168 \\
\hline Free air & 0.784 & 0.825 & 0.209 & 3.264 \\
\hline Shock state & 0.064 & 2.750 & 0.942 & 8.027 \\
\hline Glucose & 0.853 & 1.001 & 0.990 & 1.012 \\
\hline Urea & 0.034 & 1.014 & 1.001 & 1.027 \\
\hline Creatinine & 0.515 & 1.103 & 0.822 & 1.480 \\
\hline AST & 0.349 & 1.012 & 0.987 & 1.037 \\
\hline ALT & 0.195 & 1.023 & 0.988 & 1.059 \\
\hline GGT & 0.002 & 1.053 & 1.019 & 1.088 \\
\hline LDH & 0.957 & 1.000 & 0.996 & 1.004 \\
\hline ALP & 0.033 & 1.011 & 1.001 & 1.022 \\
\hline Total protein & 0.681 & 0.890 & 0.510 & 1.553 \\
\hline Albumin & 0.138 & 0.564 & 0.264 & 1.201 \\
\hline Calcium & 0.070 & 0.481 & 0.218 & 1.061 \\
\hline Sodium & 0.143 & 0.895 & 0.771 & 1.038 \\
\hline Potassium & 0.875 & 0.929 & 0.371 & 2.324 \\
\hline CRP & 0.477 & 1.002 & 0.997 & 1.006 \\
\hline Amilase & 0.559 & 0.997 & 0.989 & 1.006 \\
\hline WBC & 0.073 & 0.897 & 0.797 & 1.010 \\
\hline HGB & 0.348 & 0.910 & 0.748 & 1.108 \\
\hline HCT & 0.827 & 0.992 & 0.922 & 1.067 \\
\hline PLT & 0.500 & 1.002 & 0.997 & 1.006 \\
\hline
\end{tabular}

BMI: body mass index; ASA: American Society of Anesthesiologists; APACHE: acute physiology and chronic health evaluation; MPI: Mannheim peritonitis index; AST: aspartate aminotransferase; ALT: alanine aminotransferase; GGT: Gamma glutamyl transferase; LDH: lactate dehydrogenase; ALP: alkaline phosphatase; CRP: C reactive protein; WBC: white blood cells; HGB: hemoblobin; HCT: hematocrit; PLT: platelet

Table 8. Most significant variables for morbidity

\begin{tabular}{|lcccc|} 
& p & OR & \multicolumn{2}{c|}{$95.0 \%$ C.I. } \\
\hline BMI & 0.001 & 1.223 & 1.085 & 1.379 \\
\hline GGT & 0.003 & 1.045 & 1.015 & 1.076 \\
\hline ALP & 0.075 & 1.015 & 0.999 & 1.031 \\
\hline
\end{tabular}

BMI: body mass index; GGT: gamma glutamyl transferase; ALP: alkaline phosphatase

\section{DISCUSSION}

Perforation is the second most common complication of peptic ulcer disease following hemorrhage, with an incidence ranging from 3.77 to 14 in 100,000 (6-10). High rates of morbidity (20\%-
Table 9. Multivariate logistic regression analysis for morbidity

\begin{tabular}{|llcccc|}
\hline & & p & OR & \multicolumn{2}{c}{$95.0 \%$ C.I. } \\
\hline $\begin{array}{l}\text { Enter } \\
\text { method }\end{array}$ & Gender & 0.702 & 0.728 & 0.143 & 3.705 \\
\cline { 2 - 5 } & Age & 0.017 & 1.050 & 1.009 & 1.092 \\
& $\begin{array}{l}\text { Time from onset of } \\
\text { symptoms }\end{array}$ & 0.969 & 0.993 & 0.706 & 1.396 \\
& MPI score & 0.158 & 1.117 & 0.958 & 1.302 \\
& APACHE II score & 0.133 & 0.840 & 0.670 & 1.055 \\
& Perforation diameter & 0.442 & 0.964 & 0.877 & 1.059 \\
& Free air & 0.526 & 0.598 & 0.122 & 2.925 \\
\hline $\begin{array}{l}\text { Backward } \\
\text { method }\end{array}$ & Age & $<0.001$ & 1.046 & 1.020 & 1.073 \\
\hline
\end{tabular}

Model: gender, age, time fromonset of symptoms, MPI score, APACHE II score, perforationdiameter, freeair

MPI: Mannheim peritonitis index; APACHE: acute physiology and chronic health evaluation

$50 \%)$ and mortality (3\%-40\%) have been reported for patients surgically treated for PUP (11-14). There are many studies about the risk factors for these high mortality and morbidity rates. In our study, there were statistically significant differences between groups with regard to the average values for age, BMI, perforation diameter, APACHE II score, and MPI score $(p<0.001)$.

The diagnosis of PUP is most often made using the initial plain abdominal X-ray (15-17). In our study, 98 (87.5\%) patients were diagnosed using the initial plain abdominal X-ray. The presence of subdiaphragmatic free air did not have a statistically significant relationship with mortality or morbidity. Wakayama et al. (18) reported WBC counts below $9500 / \mathrm{mm}^{3}$ was a significant predictor of mortalityHowever, no significant effect of WBC count on mortality or morbidity was observed in our study.

Ninety-seven (86.6\%) of the 112 patients included in the study were male and 15 (13.4\%) were female. Most (71.4\%-94.5\%) of the patients with PUP are reported to be male (19-23). However, Sonnenberg (24) has displayed in his study that the ratio of females is increasing and has claimed that female gender is a risk factor for postoperative morbidity. On the contrary, Nomani et al. (25) reported the negative effect of male gender on mortality and morbidity. In our study, no prognostic value of gender was detected. Testini et al. (26) have reported that patients aged 65 years or more have significantly higher rates of mortality compared with younger patients and explained this finding with the increased incidence of accompanying diseases in the elderly patients. Similarly, in our study, older age was determined to have a significant effect on mortality and morbidity. In the study of Kim et al. (2), it was determined that the presence of accompanying diseases did not have a significant effect on postoperative mortality and morbidity. On the other hand, numerous studies have shown that the presence of accompanying diseases has a significant effect on postoperative mortality and morbidity. In these studies, pulmonary diseases, hypertension ( $\mathrm{HT})$, diabetes mellitus (DM), and cardiac diseases were found to be of importance with varying frequency $(5,27,28)$. In our study, the presence of DM, HT, renal failure, heart failure, COPD, and malignancies was observed to be related with a significantly increased risk of postoperative mortality and morbidity. 


\begin{tabular}{|c|c|c|c|c|}
\hline & p & OR & \multicolumn{2}{|c|}{$95 \%$ C.I. } \\
\hline Age & $<0.001$ & 1.125 & 1.058 & 1.197 \\
\hline Gender (female) & 0.169 & 2.781 & 0.648 & 11.945 \\
\hline BMI & 0.004 & 1.254 & 1.074 & 1.465 \\
\hline ASA & $<0.001$ & 10.203 & 3.505 & 29.699 \\
\hline Accompanying disease & 0.001 & 17.143 & 3.441 & 85.401 \\
\hline Perforation diameter & $<0.001$ & 1.212 & 1.107 & 1.326 \\
\hline APACHE II score & $<0.001$ & 1.625 & 1.286 & 2.053 \\
\hline MPI score & $<0.001$ & 1.366 & 1.181 & 1.580 \\
\hline Freeair & 0.720 & 1.477 & 0.174 & 12.512 \\
\hline Glucose & 0.696 & 1.003 & 0.990 & 1.016 \\
\hline Urea & $<0.001$ & 1.051 & 1.027 & 1.076 \\
\hline Creatinine & 0.043 & 1.474 & 1.012 & 2.147 \\
\hline AST & 0.090 & 1.023 & 0.996 & 1.050 \\
\hline ALT & 0.352 & 0.960 & 0.882 & 1.046 \\
\hline GGT & 0.474 & 1.010 & 0.983 & 1.037 \\
\hline LDH & 0.083 & 1.003 & 1.000 & 1.007 \\
\hline ALP & 0.514 & 1.004 & 0.992 & 1.017 \\
\hline Total protein & $<0.001$ & 0.033 & 0.006 & 0.174 \\
\hline Albumin & $<0.001$ & 0.011 & 0.001 & 0.096 \\
\hline Calcium & 0.001 & 0.130 & 0.039 & 0.434 \\
\hline Sodium & 0.836 & 1.019 & 0.856 & 1.212 \\
\hline Potassium & $<0.001$ & 7.524 & 2.549 & 22.207 \\
\hline CRP & 0.001 & 1.010 & 1.004 & 1.016 \\
\hline Amilase & 0.136 & 1.005 & 0.998 & 1.011 \\
\hline WBC & 0.871 & 0.988 & 0.857 & 1.140 \\
\hline HGB & 0.004 & 0.703 & 0.552 & 0.894 \\
\hline HCT & 0.003 & 0.876 & 0.802 & 0.955 \\
\hline PLT & 0.039 & 1.006 & 1.000 & 1.012 \\
\hline
\end{tabular}

BMI: body mass index; ASA: American Society of Anesthesiologists; APACHE: acute physiology and chronic health evaluation; MPI: Mannheim peritonitis index; AST: aspartate aminotransferase; ALT: alanine aminotransferase; GGT: gamma glutamyl transferase; LDH: lactate dehydrogenase; ALP: alkaline phosphatase; CRP: C reactive protein; WBC: white blood cells; HGB: hemoblobin; HCT: hematocrit; PLT: platelet

There are many scoring systems for predicting risk of morbidity and mortality in PUP, with ASA and Boey scoring methods being the most commonly used ones (29-32). However, ASA score is used as an overall surgical risk score rather than just for predicting the risks of PUP. Also in many studies, high MPI and APACHE II scores were found to be related with increased mortality and morbidity. Some studies have only investigated the effects of preoperative shock state on morbidity and mortality, concluding it to be an important risk factor (26, 33-35) We used the ASA, MPI, and APACHE II scoring methods as variables in our study. According to the statistical analysis, we concluded that all three scoring methods could be used to predict the risk of mortality and morbidity.
Table 11. Multivariate logistic regression analysis for mortality

\begin{tabular}{|c|c|c|c|c|c|}
\hline & & $p$ & OR & 95.0 & $\%$ C.I. \\
\hline \multirow{7}{*}{$\begin{array}{l}\text { Enter } \\
\text { method }\end{array}$} & Gender & 0.236 & 10.320 & 0.217 & 490.9 \\
\hline & Age & 0.172 & 1.063 & 0.974 & 1.161 \\
\hline & $\begin{array}{l}\text { Time from onset of } \\
\text { symptoms }\end{array}$ & 0.125 & 1.875 & 0.840 & 4.186 \\
\hline & MPI score & 0.530 & 1.090 & 0.832 & 1.428 \\
\hline & APACHE II score & 0.159 & 1.489 & 0.855 & 2.594 \\
\hline & Perforation diameter & 0.197 & 1.101 & 0.952 & 1.273 \\
\hline & Free air & 0.080 & 79.742 & 0.589 & 10793.3 \\
\hline \multirow{3}{*}{$\begin{array}{l}\text { Backward } \\
\text { method }\end{array}$} & Age & 0.035 & 1.079 & 1.006 & 1.159 \\
\hline & $\begin{array}{l}\text { Time from onset of } \\
\text { symptoms }\end{array}$ & 0.069 & 1.593 & 0.965 & 2.629 \\
\hline & APACHE II score & 0.026 & 1.506 & 1.051 & 2.157 \\
\hline
\end{tabular}

Model: Gender, age, time from onset of symptoms, MPI score, APACHE II score, perforation diameter, free air

MPI: Mannheim peritonitis index; APACHE: acute physiology and chronic health evaluation

Nomani et al. (25) have reported a worse prognosis in patients with a perforation diameter greater than $5 \mathrm{~mm}$. Consistent with the literature, we found that a large perforation diameter significantly increases morbidity and mortality (26-36). Duration of postoperative hospital stay of patients operated for PUP ranges between 7 and 12.5 days (37-39). In our study, the mean duration of hospital stay was $11.7 \pm 11.3$ days in the morbidity group and $5.3 \pm 1.1$ days in the no complication group. The duration of postoperative hospital stay in the morbidity group was significantly longer than that in the no complication group $(p<0.001)$. In their study with 2668 patients, Buck et al. (40) have calculated a two-fold risk of mortality for underweight patients operated for PUP, and determined that being obese has no positive or negative effect on mortality. In our study, for patients with an increased BMI, mortality and morbidity were also significantly increased in both univariate and multivariate analysis $(p<0.001)$.

\section{CONCLUSION}

Peptic ulcer perforation continues to be an important cause of mortality and morbidity. We think that a novel vision to avoid gaps is necessary to evaluate the patients with PUPsas surgeons are coming across new types of patient profile in last decades. Mortality and morbidity are increased in patients with older age and higher BMI, perforation diameter, and APACHE II and MPI scores. We hypothesize that through closer follow-up of these patients, rates of mortality and morbidity can be decreased.

Ethics Committee Approval: Ethics committee approval was received for this study from the ethics committee of Haseki Training and Research Hospital.

Informed Consent: Written informed consent was obtained from patient who participated in this study.

Peer-review: Externally peer-reviewed. 
Author Contributions: Concept - A.H., C.T., D.Y.; Design - A.H., C.T.; Supervision - C.T., A.K., M.A.; Resource - A.H., C.T., A.K.; Materials - C.T., D.Y., T.D., A.U.; Data Collection and/or Processing - D.Y., T.D., A.U., A.K., M.A.; Analysis and/or Interpretation - C.T., T.D., A.K., M.A.; Literature Search C.T., A.U.; Writing Manuscript - A.H., C.T.; Critical Reviews - T.D., A.K., M.A.

Conflict of Interest: No conflict of interest was declared by the authors.

Financial Disclosure: The authors declared that this study has received no financial support.

\section{REFERENCES}

1. Dempsey DT. Stomach. In; Brunicardi FC (ed). Schwartz's principles of surgery, 8th ed. New York: Mc Graw-Hill; 2006, pp. 650-685.

2. Kim JM, Jeong SH, Lee YJ, Park ST, Choi SK, Hong SC, et al. Analysis of risk factors for postoperative morbidity in perforated peptic ulcer. J Gastric Cancer 2012; 12: 26-35. [CrossRef]

3. Chalya PL, Mabula JB, Koy M, McHembe MD, Jaka HM, Kabangila $\mathrm{R}$, et al. Clinical profile and outcome of surgical treatment of perforated peptic ulcers in Northwestern Tanzania: A tertiary hospital experience. World J Emerg Surg 2011; 6:31. [CrossRef]

4. Mäkelä J, Laitinen S, Kairaluoma MI. Complications of peptic ulcer disease before and after the introduction of $\mathrm{H} 2$-receptor antagonists. Hepatogastroenterology 1992; 39: 144-148.

5. Noguiera C, Silva AS, Santos JN, Silva AG, Ferreira J, Matos E, et al. Perforated peptic ulcer: main factors of morbidity and mortality. World J Surg 2003; 27: 782-787. [CrossRef]

6. Lassen A, Hallas J, Schaffalitzky de Muckadell OB. Complicated and uncomplicated peptic ulcers in a Danish county 1993-2002: a population-based cohort study. Am J Gastroenterol 2006; 101: 945-943. [CrossRef]

7. Higham J, Kang JY, Majeed A. Recent trends in admissions and mortality due to peptic ulcer in England: increasing frequency of haemorrhage among older subjects. Gut 2002; 50: 460-464. [CrossRef]

8. Bardhan KD, Williamson M, Royston C, Lyon C. Admission rates for peptic ulcer in the Trent region, UK, 1972-2000. Changing pattern, a changing disease? Dig Liver Dis 2004; 36: 577-588. [CrossRef]

9. Canoy DS, Hart AR, Todd CJ. Epidemiology of duodenal ulcer perforation: a study on hospital admissions in Norfolk, United Kingdom. Dig Liver Dis 2002; 34: 322-327. [CrossRef]

10. Lau JY, Sung J, Hill C, Henderson C, Howden CW, Metz DC. Systematic review of the epidemiology of complicated peptic ulcer disease: Incidence, recurrence, risk factors and mortality. Digestion 2011; 84: 102-113. [CrossRef]

11. Christensen S, Riis A, Norgaard M, Sørensen HT, Thomsen RW. Short-term mortality after perforated or bleeding peptic ulcer among elderly patients: a population-based cohort study. BMC Geriatr 2007; 7: 8-9. [CrossRef]

12. Soreide $K$, Thorsen $K$, Soreide JA. Predicting outcomes in patients with perforated gastroduodenal ulcers: artificial neural network modelling indicates a highly complex disease. Eur J Trauma EmergSurg 2015; 41: 91-98. [CrossRef]

13. Lau JY, Sung J, Hill C, Henderson C, Howden CW, Metz DC. Systematic review of the epidemiology of complicated peptic ulcer disease: incidence, recurrence, risk factors and mortality. Digestion 2011; 84: 102-113. [CrossRef]

14. Bae S, Shim KN, Kim N, Kang JM, Kim DS, Kim KM, Cho YK, Jung SW. Incidence and short-term mortality from perforated peptic ulcer in Korea: a population-based study. J Epidemiol 2012; 22: 508-516. [CrossRef]

15. Druart ML, Van Hee R, Etienne J, Cadirere GB, Gigot JF, Legrant M. Laparoscopic repair of perforated duodenal ulcer. A prospective multicenter clinical trial. Surg Endosc 1997; 11: 1017-1020. [CrossRef]

16. Koskensalo S, Leppaniemi A. Perforated Duodenal Ulcer: Has anything changed? Eur J Trauma Emerg Surg 2010; 36: 145-150. [CrossRef]

17. Lemaitre J, Founas WE, Simoens C, Ngongang C, Smets D, Costa PM Surgical management of acute perforation of peptic ulcers. A single centre experience. Acta Chir Belg 2005; 105: 588-591. [CrossRef]
18. Wakayama T, Ishizaki $Y$, Mitsusada M, Takahashi S, Wada T, Fukushima $Y$, et al. Risk factors influencing the short-term results of gastroduodenal perforation. Surg Today 1994; 24: 681-687. [CrossRef]

19. Heo IU, Kim HK, Lee SZ. A clinical study on peptic ulcer perforation. J Korean Surg Soc 1984; 27: 567-575.

20. Kang G, Kim CY, Min YD, Kim SH. Results of surgical treatment for perforated peptic ulcer. J Korean SurgSoc 1993; 44: 214-222.

21. Lee HW, Ahn SI, Yang DH, Lee CH, Sohn JH, Kwon OJ, et al. A clinical review of peptic ulcer during 22 yrs (1968 1989). J Korean SurgSoc 1993; 44: 159-174.

22. Bae SW, Hwang JY, Lee YG. A clinical study of perforated peptic ulcer. J Korean Surg Soc 1989; 36: 737-743.

23. Shin HW, Moon SH, Lee YC, Kim JS, Chung BW, Chung KS. APACHE II score in emergency operation for perforation of gastroduodenal ulcer. J Korean Surg Soc 1994; 47: 501-509.

24. Sonnenberg A. Changes in physician visits for gastric and duodenal ulcer in the United States during 1958-1984 as shown by National Disease and Therapeutic Index (NDTI). Dig Dis Sci 1987; 32: 1-7. [CrossRef]

25. Nomani AZ, Qureshi MS, Malik AK. A new scoring system for perforation peritonitis secondary to duodenal ulcers. J Pak Med Assoc 2014; 64: 50-56.

26. Testini M, Portincasa P, Piccinni G, Lissidini G, Pellegrini F, Greco L. Significant factors associated with fatal outcome in emergency open surgery for perforated peptic ulcer. World J Gastroenterol 2003; 9: 2338-2340. [CrossRef]

27. Jeong SH, Ahn HS, Yoo MW, Cho JJ, Lee HJ, Kim HH, et al. In creased morbidity rates in patients with heart disease or chronic liver disease following radical gastric surgery. J SurgOncol 2010; 101: 200-204. [CrossRef]

28. Schiff RL, Welsh GA. Perioperative evaluation and management of the patient with endocrine dysfunction. Med Clin North Am 2003; 87: 175-192. [CrossRef]

29. Thorsen K, Soreide JA, Soreide K. Scoring systems for outcome prediction in patients with perforated peptic ulcer. Scand J Trauma Resusc Emerg Med 2013; 21: 25-34. [CrossRef]

30. Lohsiriwat V, Prapasrivorakul S, Lohsiriwat D. Perforated peptic ulcer: clinical presentation, surgical outcomes, and the accuracy of the Boey scoring system in predicting postoperative morbidity and mortality. World J Surg 2009; 33: 80-85. [CrossRef]

31. Arenal JJ, Bengoechea-Beeby M. Mortality associated with emergency abdominal surgery in the elderly. Can J Surg 2003; 46: 111 116.

32. Boey J, Choi SK, Poon A, Alagaratnam TT. Risk stratification in perforated duodenal ulcers. A prospective validation of predictive factors. Ann Surg 1987; 205: 22-26. [CrossRef]

33. Chan WH, Wong WK, Khin LW, Soo KC. Adverse operative risk factors for perforated peptic ulcer. Ann Acad Med 2000; 29: 164-167.

34. Koçer B, Sürmeli S, Solak C, Unal B, Bozkurt B, Yıldırım O, et al. Factors affecting mortality and morbidity in patients with peptic ulcer perforation. J Gastroenterol Hepatol 2007; 22: 565-570. [CrossRef]

35. Arici C, Dinckan A, Erdogan O, Bozan H, Colak T. Peptic ulcer perforation: an analysis of risk factors. Ulus Travma Derg 2002; 8: 142146.

36. Lee FY, Leung KL, Lai BS, Ng SS, Dexter S, Lau WY. Predicting mortality and morbidity of patients operated on for perforated peptic ulcers. Arch Surg 2001; 136: 90-94. [CrossRef]

37. Taş I, Ülger BV, Önder A, Kapan M, Bozdağ Z. Risk factors influencing morbidity and mortality in perforated peptic ulcer disease. Turk J Surg 2015; 31: 20-25. [CrossRef]

38. Kamani F, Mogimi M, Marashi SA, Peyrovi H, Sheikhvatan M. Perforated peptic ulcer disease: mid-term outcome among Iranian population. Turk J Gastroenterol 2010; 21: 125-128. [CrossRef]

39. Çakır M, Küçükkartallar T, Tekin A. Changing surgical methods in peptic ulcer perforation. Selçuk Üniv Tıp Derg 2011; 27: 160-161.

40. Buck DL, Moller MH. Influence of body mass index on mortality after surgery for perforated peptic ulcer. Br J Surg 2014; 101: 993999. [CrossRef] 